safety procedures - individual protection - medical surveillance. The presentation ended with an outline of concepts for the future.

Use of information systems in occupational medicine - Wg Cdr AC Wilcock.

This presentation discussed the relevance of information systems to support occupational medicine. There is a requirement for personnel data (personal identifiers, health status, sickness absence, and ill-health retirement), workplace data (hazards, risks and exposure) and data on occupational medicine outputs and costs. This must include a mechanism for integration of data and data storage. The Armed Forces have an advantage over other occupational medicine systems by providing a comprehensive health service for its uniformed employees. The basis for the occupational medicine component of health records could be found from $\mathrm{COSHH}$ regulations. The existing Armed Forces Primary Health Care Information System may provide an opportunity to develop such a system. The presentation reviewed a trial called Occupational Medical Data Set linked to EMIS. GPs were asked to link attendance with exposure to hazards at work. The results showed $23 \%$ of attendances were related to occupation, $12 \%$ for medical assessments and $15 \%$ for mental disorders classified as causedby occupation. The trial demonstrated a capability to create a centralised medical dataset that could be used to provide information to support policy, planning and research.

There were the following poster presentations: The Hazards of Military Parachuting - Major MCM Bricknell, The Effects of $\bigcirc$ Arduous Physical Exercise on a Group of Haematological,o Biological and Immunological Measurements in Blood - HA Chander, PO Collinson, MD Simmons and D Lewis, ands్ Quality in Occupational Health - RAF Institute of Health. In addition IMN had series of posters on communication in RNㅡㅡㄹ damage control, transfer of casualties with spinal injuries in $\mathrm{HM}_{\bar{\rho}}^{\overline{\widehat{D}}}$ ships and submarines, survival in a disabled submarine and the $\stackrel{乛}{\varrho}$ effectiveness of electrolyte beverages on short-termis dehydration.

The symposium was an unqualified success providing an excellent opportunity for Tri-service communication through $\vec{\omega}$ both the formal presentations and informal discussion. The papers proved the continued high academic quality of Service occupational medicine. It is hoped to make this symposium a? regular event.

\title{
REPORT
}

\section{Symposium - Commemoration of the Liberation of the Bergen-Belsen Concentration Camp and Medical Management of Disasters Study Period}

\author{
Lt Col RF Cordell \\ BSc,MB,BS,MRCGP,DCH,DRCOG,DipIMC,RCSEd,RAMC \\ Commanding Officer
}

1 Armd Fd Amb RAMC, Glyn Hughes Barracks, BFPO 30

\author{
Dr DH Forsdick \\ $\mathrm{MB}, \mathrm{BS}$ \\ Retired General Practitioner
}

Winchester, Hants

SUMMARY: Over the period 15/16 April 1998 a commemorative dinner and study period was held to recognise the role of the medical services in the management of the victims of the Bergen-Belsen Concentration Camp. Having been presented

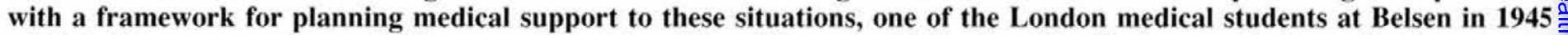
related his own experience at this unprecedented and horrific scene. Following this, the lessons that may be drawn were examined, the key factor being the need to create order out of chaos. The system used by the military for analysing what has $\underline{3}$. to be achieved in a given situation, and the deductions that can be made from the prevailing factors, called the Estimate $\stackrel{\odot}{\circ}$ Process, emerged as a model for planning the medical contribution to disaster relief.

\section{Introduction}

The Centenary of the Royal Army Medical Corps was marked by 1 Armoured Field Ambulance with a commemorative dinner and study period on 15/16 April 1998. This event recognised the contribution of medical personnel to the liberation of the nearby Bergen-Belsen Concentration Camp 53 years previously, and examined the lessons that can be drawn from the experience of this and other disasters. The key individual, who directed the medical relief effort, was Brigadier Glyn Hughes CBE DSO and two bars MC, after whom our barracks in Hohne Camp, North Germany, is named.

Following the fortieth anniversary of the Second World War, articles were published in this journal $(1,2)$ relating the part played by members of the RAMC in the liberation of Belsen in April 1945. These reflect the efforts of 32 Casualty Clearing Station, under the command of Lt Col JAD Johnston MC, and

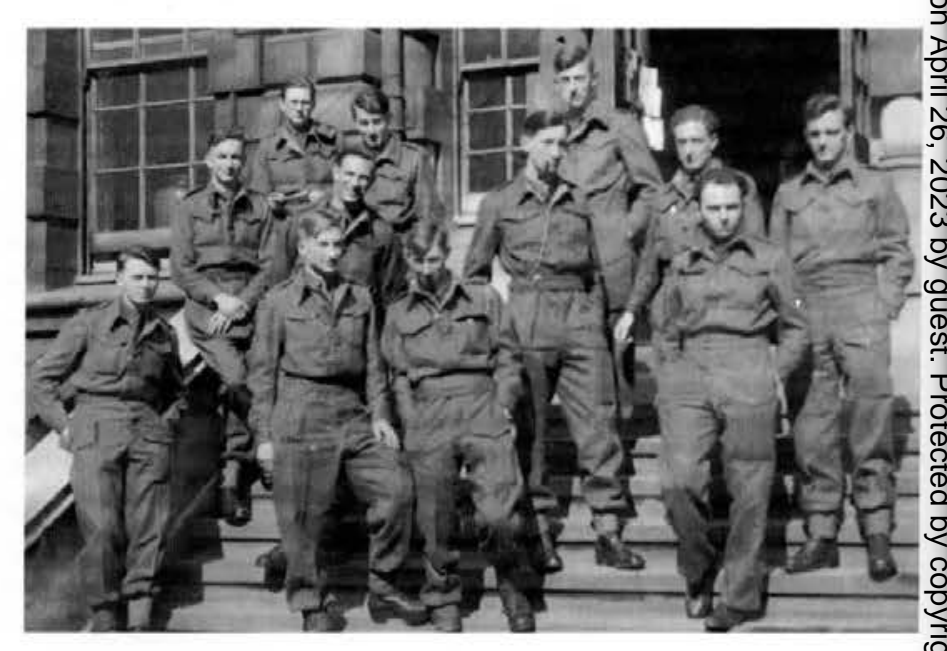


11 (Light) Field Ambulance, under the command of Lt Col W $\mathrm{M}$ Gonin, and others in the early days after liberation. In researching this, one of us (RC) came across the name DH Forsdick (2), being one of the London medical students that came to Belsen in 1945. By coincidence, RC had taken over Dr Forsdick's practice on his retirement in 1987, but had not previously been aware of his contribution to the relief of Belsen. He was therefore invited as the principal speaker at this commemorative event.

The commemoration began with a visit to the Memorial at Bergen-Belsen, at which the curator, Dr Rahe, gave a highly informative and moving talk on the formation of the camp and its liberation, and the present day work of the document centre. Just prior to the Commemorative Dinner, the Curator of the RAMC Museum, Capt (Retd) PH Starling, gave an account of the work of Brigadier Glyn Hughes. This truly remarkable doctor and soldier had fought in both world wars, played Rugby at national level, was a GP in Kensington, and yet still had enough time to be a TA officer between the wars. Having been evacuated from Dunkirk, he then commanded 141 Field Ambulance in Dunblane, and by the closing stages of the fighting in Germany he was the senior medical officer (DDMS) to the British Second Army.

On 16 April, Lt Col A Hawley OBE gave an overview of the medical management of disasters, using his experience in Rwanda in 1994 as an example. Dr Forsdick then gave his presentation, which was based on an article he wrote for the Guy's Hospital Gazette in 1945. There follows a transcript of this contemporary account of his experience; although two letters he sent back from Belsen were published, this full account has not previously been related.

\section{Journey to Belsen, May 1945}

On May 2nd, 1945, ninety eight London medical students travelling under the auspices of the British Red Cross and Order of St John of Jerusalem arrived at Belsen, Germany. They were sent to help with medical administration in the recently liberated concentration camp.

Belsen had two main areas; Camp 1, being the concentration camp itself, and Camp 2, where the SS guards were quartered. It was in the latter that the students resided, but their work lay in the concentration camp. This had been liberated by British troops on April 15th, and on May 2nd, 27,000 internees were still there; many of the fitter had already unofficially evacuated themselves, but the death rate was still five to seven hundred per day.

Camp 1 consisted of some 200 wooden huts into which the internees had been crowded. There was no sanitation, and for several days prior to liberation there had been no food or water. Typhus was widespread; in fact hardly any had been spared that scourge. The prisoners' bodily condition was pitiful. The vast majority were terribly emaciated from their prolonged starvation, and the weaker prisoners had not been able to get any food as the stronger ones had stolen it from them.

As an example, one of the huts, measuring some 30 yards long, 7 yards wide and 10 feet high, had housed no less than 2000 prisoners. They had been packed inside one on top of the other, and many had been suffocated to death within the first few hours of their confinement. They were not permitted to leave the huts, except when they were taken away to work, so that everything they had to do was done inside; urinating, defaecating, vomiting and dying. No provision had been made for the sick and no medical treatment had been given to them. Some experimental work, of a primitive and sadistic nature, had been performed; for example, the intravenous injection of Benzene in an attempt to produce artificial arteriosclerosis. The doctor in charge of such work was the "Mad Doctor of Belsen", J Dr Klein.

At the time of liberation, naturally the internees broke out of their huts, but were not allowed outside the confines of the $\bar{z}$ concentration camp for health reasons. Everyone suffered from $\stackrel{\varnothing}{\varnothing}$ violent diarrhoea, and thus it was not long before the ground $\bigcirc$ was made filthy with every kind of mess imaginable. Piles of dead were everywhere, and many lay around outside their huts dying. By May 2nd, when the medical students arrived, the $\stackrel{\vec{\rho}}{\rightarrow}$ larger piles of dead had been buried in mass graves by the SS $\overrightarrow{0}$ guards, under the supervision of the liberating troops. Already $\frac{\overline{\bar{O}}}{\bar{\omega}}$ some of the barracks in Camp 2 were being converted into hospital blocks where each sick person was assured of a bed and food, even if the medical treatment was minimal.

The duties of the students during the first two weeks were $\overrightarrow{0}$ generally as follows. Each was allotted one or two huts, $\overrightarrow{\vec{\omega}}$ according to the number of prisoners therein, and a team of $\stackrel{\omega}{\sigma}$ Hungarian guards, who were instructed to clean out the huts and assist with the feeding of the sick. The students' chief concerns were to try to produce some degree of cleanliness, however slight, and to supervise the feeding of the internees and see that everyone, not merely the stronger, got food. The students would do as much as they could regarding treatment, but the only drugs available were Opium tablets, Sulphathiazole, Aspirin, and Tanalbin, a German preparation of tannic acid and albumen for the treatment of diarrhoea.

Common conditions were typhus and its complications, stomatitis, active pulmonary tuberculosis, and many hundreds of grossly septic lesions produced by the appalling living conditions. Diarrhoea was prevalent, and the majority were extremely emaciated, seemingly a framework of bones covered by yellow parchment. Some prisoners did not know who they were, and many had no idea whence they had come. Society's accepted moral values were for the most part totally absent, and all signs of modesty had disappeared, even from the women.

Few people were able to cope with the normal diet and many would vomit up everything given them, even the vitaminglucose mixture which became so popular. The food prepared by the cookhouse, now under British military supervision, consisted of Bengal famine mixture (dried milk, flour, sugar and salt), stew and boiled potatoes. A small supply of tinned meats, sardines, tinned fruit, cigarettes and chocolate was available and rationed out to each block. In addition, a kitchen was set up to produce the vitamin-glucose mixture and protein hydrolysate. The former was extremely popular, the latter distasteful to everyone despite attempts to flavour it with Oxo, Bovril and cocoa. The protein hydrolysate was administered to those suffering from famine oedema, and unable to take proper food. Often this could not be taken orally, and so nasal feeding was attempted, but without success as the tubes were not tolerated by the vast majority. In the end, the most satisfactory treatment for famine oedema was transfusion with twice concentrated plasma.

Each day internees were evacuated to better conditions in Camp 2. The fit were accommodated in blocks similar te those housing the students, which were very comfortable indeed, with running water in each room, electric light and stoves. The sick were removed to hospital blocks, first passing through the "Human Laundry". This was in the Camp 2 stables, where German nurses under the supervision of German military doctors, in turn supervised by RAMC personnel, would scrub the internees with soap and water and then dust them with delousing powder (DDT).

On May 21st, the last hut within the concentration camp was ceremoniously destroyed by flame throwers, and so the work of the students was then confined to the hospital. A nearby

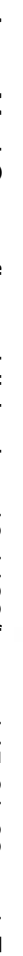


German hospital, later named Glyn Hughes Hospital, was also used for the treatment of internees. An attempt was made to supply a diet of some 3000 calories to those able to cope with such an amount. A serious difficulty presented itself, as approximately half the intended quantity of food arrived at the patient, the remainder being stolen somewhere between the kitchen and bedside. This dishonesty was noticeable everywhere, the result of the existence these unhappy people were forced to suffer under the Nazis. On the whole, this behaviour persisted while the former internees were in hospital, that is every man for himself; the survival of the fittest.

Ten days after Camp 1 had been completely emptied, the diarrhoea, previously so common, was definitely on the wane. Among other cases found in the hospitals were cancrum oris, pellagra and Wernicke's Syndrome. The actual number of cases of tuberculosis could not be quantified; although some presented the most vivid symptoms, others were more silent, yet badly infected. Radiography was minimal, the Glyn Hughes Hospital being able to take a maximum of 20 films per day. Slowly some of the sick recovered, but all too many seemed beyond human aid, especially with the limited treatment they could then receive at Belsen.

A few days before the British medical students left on May 20th, some Belgian students arrived to take over their medical duties. In the time they were there, certain measures were essential to safeguard their own health, which included taking a bath as often as possible (there was an excellent bath house in Camp 2 near the students' quarters) and dusting with de-lousing powder at least once per week, whenever a change of clothes had been made, or whenever desired by the individual. Of the ninety eight students who went to Belsen, only seven subsequently developed typhus, an admirable result in view of the filthy surroundings in which they were obliged to work in Camp 1.

Belsen was an experience never to be forgotten, and must be, for the rest of the world, an atrocity always to be remembered.

\section{Examination of the Lessons That Can Be Drawn}

Following Dr Forsdick's talk, Lt Col Hawley presented a problem to be solved in syndicates. These were a group of majors, a group of junior officers, a group of warrant officers and senior NCOs, and a group of junior NCOs. Each was led by a Lieutenant Colonel facilitator. The subsequent presentations showed a different approach by each group to solving the problem, but the central message shone through. The detail of medical treatments, feeding regimes and so forth will be assessed at the time on the basis of the best contemporary evidence of efficacy, but the enduring principle is that order must be brought out of chaos. To do this, first and foremost the mission needs to be defined. In other words, the actual role of the medical component, and how this fits in with the overall effort (which will include other national, international and non- governmental agencies), must be clear. Lt Col Hawley related how his own mission was not stated at the outset, and he had to define it himself. This process is familiar within the military as Mission Analysis. The various factors affecting how this mission is to be carried out are then considered, and key tasks identified and resources allocated, following which alternative courses of action are considered. From this, the medical plan is developed and promulgated. Training in this logical assessment system, the Estimate Process, is an invaluable grounding for making an effective contribution to the relief of disasters on the scale of those at Belsen.

\section{Training for Disaster Relief Operations}

There has been a great deal of interest in training for the medical aspects of disaster relief, including courses such as those developed by $\mathrm{Lt} \mathrm{Col}$ Hawley in his time as the Chief Instructor at the Defence Medical Services Training Centre. A Diploma examination in this subject can be sat, and indeed is popular among military medical officers. There is no substitute for actual experience in this field, and indeed in recent years the Defence Medical Services have contributed a great deal to disaster relief operations across the globe. However, practical training in aspects of this work can be found on Exercise SHARP POINT, being a medical exercise run in remote parts of Kenya, providing immunisations and other medical care within the framework of aid agencies and the Government of Kenya. RC related his experience of the first of these exercises in 1995, as a model for training in the complex issues surrounding medical support to disaster relief operations.

\section{Conclusion}

All taking part in this Commemoration of the liberation of Bergen-Belsen, in this RAMC Centenary year, were immensely grateful to Dr Forsdick for coming back to Belsen for this first time in 53 years. His personal experience was unmatched, and allowed many of those taking part to ask him how he coped with what must have been appalling conditions. He replied that although all the students had been in London during the Blitz, and had been used to dealing with people with the most horrific injuries, the scene at Belsen was completely alien to anything that had gone before. The stench of the place was of itself oppressive, and yet the scene seemed completely unreal. Perhaps the outrageousness and scale of the disaster allowed a sense of detachment to develop, so that one could carry on with the work that had to be done in these most appalling of conditions.

\section{REFERENCES}

1. Prescott DT. Reflections of Forty Years Ago - Belsen 1945. J R Army Med Corps 1986; 132: 48-51.

2. Vella EE. Belsen: Medical Aspects of a World War II Concentration Camp. J R Army Med Corps 1984; 130: 34 59. 